\title{
The climate change influences and trends on the grapevine growing in Southern Romania: A long-term study
}

\author{
G.M. Bucur, G.A. Cojocaru, and A.O. Antoce ${ }^{\mathrm{a}}$ \\ University of Agronomic Sciences and Veterinary Medicine of Bucharest, 59 Marasti Blvd, District 1, Bucharest, Romania
}

\begin{abstract}
The topography and pedoclimatic conditions in Romania are diverse and in many places highly favourable for viticulture. In the past 21 years it was observed that the climate slowly changed, with a visible impact on grape quality. The influence of climate change on grape growing depends however on the vineyard location, relief and soil, multiple combination of varieties and rootstocks, water supply, as well as viticultural practices. The influence of the climate change was studied during a long period of time, between 1998

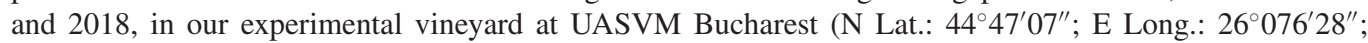
elevation $87 \mathrm{~m}$ ), located in the Southern part of Romania. The observations made during last twenty one years on qualitative and quantitative parameters of the most widespread Romanian grape variety, Fetească regală grafted on the Kober 5 BB rootstock, along with the calculated values for the usual climatic indices describing viticultural climate, showed some significant climate changes in comparison with a reference period between 1961 and 1997 taken from the existent scientific literature. Our observations during past twenty years reveal a trend of increase in all studied temperature-dependent climatic indices during the grape growing season, with a large variation in the absolute minimum temperatures during winter, which suggests a shift towards an increased thermal amplitude between summer and winter temperatures in certain years. Compared with the reference period (1961-1997), an increase in the following temperature-dependent indices was observed: $+0.75^{\circ} \mathrm{C}$ for the average annual temperature; $+0.78^{\circ} \mathrm{C}$ for average temperature in the growing season; $+2.37^{\circ} \mathrm{C}$ for average maximum temperature in the warmest month; $+2.11^{\circ} \mathrm{C}$ for average maximum temperature in the summer; +234 units in Huglin index; +173 units in Winkler index and $+0.35^{\circ} \mathrm{C}$ in $\mathrm{Cool}$ night index. These climate changes bring important variations of grape yield due to the minimum temperatures during winter and significant reduction of total acidity, along with a significant increase of sugar concentration. This study aids to understand and anticipate the rate of climate change in Southern Romania, the extent of the changes in grape quality and the interventions required to maintain constant grape and wine quality.
\end{abstract}

\section{Introduction}

It is known that the grapevine is particularly sensitive to climate change, so that it can be considered as an indicator plant in this field. In the last decades the impact of climate change was studied on several Romanian wine regions [1-7]. These studies revealed the effects of climate warming on the evolution of phenological stages [8], on grapevine growth and developement, on grape yield and quality. Studies have also been conducted to recommend adaptation of viticultural practices to climate change [9], as well as for the re-assessment of climate suitability for the wine production of Romanian wine growing regions $[10,11]$. In various vineyards of the world, important researches have been carried out on the effects of climate change and the adaptation of viticulture to the new conditions [12-16].

Internationally there is a rising interest in climate change impact on vineyards. Thus, joining these efforts, the aim of this work was to investigate the tendencies of 14 climatic parameters and 3 bioclimatic indices for the reference period of 1961-1997 and for the

\footnotetext{
a e-mail: aantoce@yahoo.com; arina.antoce@

horticultura-bucuresti.ro
}

present-time period of 1998-2018 in the vineyard of University of Agronomic Sciences and Veterinary Medicine of Bucharest.The climatic data allow the analysis of climate evolution over a long period of time, as well as the characterization and quantification of global warming in the area of Bucharest.

\section{Materials and methods}

The data recorded at Bucharest-Baneasa meteorological station $\left(44^{\circ} 43^{\prime} \mathrm{N} ; 26^{\circ} 10^{\prime} \mathrm{E}\right)$ were used for the present study. The present analysis is based on the observation data recorded over a period of 20 years (1998-2018), compared with the reference period of the previous 36 years (1961-1997). The climatic data analysed are the average, minimum and maximum temperature, as well as the fallen precipitations. The temperature data were also used to calculate three well known bioclimatic indices, including the Winkler Index - WI (or growing degreedays index), the Huglin heliothermal Index - HI and Cool Night Index - CNI [17-19]. In the experimental plantation of the University of Agronomic Sciences and Veterinary Medicine of Bucharest, observations were made on vines for the entire 1998-2018 period. The plantation 
Table 1. The main climatic parameters and bioclimatic indices during the experimentation period (1998-2018) compared to the reference period (1961-1997).

\begin{tabular}{|c|c|c|c|}
\hline Climatic parameters and bioclimatic indices & Average 1961-1997 \pm SD & Average 1998-2018 \pm SD & Difference $( \pm)$ \\
\hline Average annual temperature, ${ }^{\circ} \mathrm{C}$ & $11.15 \pm 0.62^{\mathrm{a}}$ & $11.89 \pm 0.61^{\mathrm{b}}$ & +0.74 \\
\hline $\begin{array}{l}\text { Average temperature in the growing season } \\
(\mathrm{IV}-\mathrm{X}),{ }^{\circ} \mathrm{C}\end{array}$ & $17.64 \pm 0.62^{\mathrm{a}}$ & $18.38 \pm 0.74^{b}$ & +0.74 \\
\hline $\begin{array}{l}\text { Average temperature in summer } \\
\text { (VI-VIII), }{ }^{\circ} \mathrm{C}\end{array}$ & $21.76 \pm 0.78^{a}$ & $22.97 \pm 1.01^{\mathrm{b}}$ & +1.21 \\
\hline $\begin{array}{l}\text { Average temperature in the warmest } \\
\text { month, }{ }^{\circ} \mathrm{C}\end{array}$ & $22.89 \pm 1.12^{\mathrm{a}}$ & $24.27 \pm 1.17^{b}$ & +1.38 \\
\hline Average annual minimum temperature, ${ }^{\circ} \mathrm{C}$ & $4.93 \pm 0.62^{* a}$ & $5.27 \pm 0.63^{\mathrm{a}}$ & +0.34 \\
\hline $\begin{array}{l}\text { Average minimum temperature, in the growing } \\
\text { season }(\mathrm{IV}-\mathrm{X}),{ }^{\circ} \mathrm{C}\end{array}$ & $10.30 \pm 0.51^{* a}$ & $10.71 \pm 0.69^{b}$ & +0.41 \\
\hline $\begin{array}{l}\text { Average minimum temperature in summer } \\
\left(\text { VI-VIII) },{ }^{\circ} \mathrm{C}\right.\end{array}$ & $14.32 \pm 0.67^{* a}$ & $14.82 \pm 0.78^{b}$ & +0.50 \\
\hline $\begin{array}{l}\text { Average minimum temperature, in the warmest } \\
\text { month, }{ }^{\circ} \mathrm{C}\end{array}$ & $15.20 \pm 0.96^{* a}$ & $15.69 \pm 0.90^{\mathrm{a}}$ & +0.49 \\
\hline Average of absolute minimum temperature, ${ }^{\circ} \mathrm{C}$ & $-15.87 \pm 3.61^{\mathrm{a}}$ & $-18.76 \pm 4.27^{\mathrm{b}}$ & -2.89 \\
\hline Absolute minimum temperature, ${ }^{\circ} \mathrm{C}$ & -23.7 & -25.7 & -2 \\
\hline Average annual maximum temperature, ${ }^{\circ} \mathrm{C}$ & $16.50 \pm 0.93^{* a}$ & $17.75 \pm 0.65^{\mathrm{b}}$ & +1.24 \\
\hline $\begin{array}{l}\text { Average maximum temperature in the growing } \\
\text { season (IV-X), }{ }^{\circ} \mathrm{C}\end{array}$ & $23.89 \pm 0.72^{* a}$ & $25.15 \pm 0.90^{\mathrm{b}}$ & +1.26 \\
\hline $\begin{array}{l}\text { Average maximum temperature in summer } \\
\left(\text { VI-VIII), }{ }^{\circ} \mathrm{C}\right.\end{array}$ & $28.10 \pm 0.96^{* a}$ & $29.99 \pm 1.26^{\mathrm{b}}$ & +1.89 \\
\hline $\begin{array}{l}\text { Average maximum temperature in the warmest } \\
\text { month, }{ }^{\circ} \mathrm{C}\end{array}$ & $29.55 \pm 1.44^{* a}$ & $31.54 \pm 1.55^{b}$ & +1.99 \\
\hline Annual total precipitation, $\mathrm{mm}$ & $613 \pm 125^{\mathrm{a}}$ & $632 \pm 152^{\mathrm{a}}$ & +19.27 \\
\hline $\begin{array}{l}\text { Total precipitation in the growing season (IV-X), } \\
\mathrm{mm}\end{array}$ & $398 \pm 116^{\mathrm{a}}$ & $419 \pm 133^{\mathrm{a}}$ & +21.05 \\
\hline Total precipitation in summer (VI-VIII), $\mathrm{mm}$ & $195 \pm 67^{\mathrm{a}}$ & $177 \pm 67^{\mathrm{a}}$ & -18.63 \\
\hline Huglin index (HI) & $2236 \pm 156^{* a}$ & $2416 \pm 149^{b}$ & +180 \\
\hline Winkler index (WI) & $1632 \pm 142^{* a}$ & $1792 \pm 159^{b}$ & +160 \\
\hline Cool night index (CNI) & $10.24 \pm 1.51^{\text {*a }}$ & $10.91 \pm 1.22^{\mathrm{a}}$ & +0.67 \\
\hline
\end{tabular}

*1977-1997; **a, b - letters indicate $T$-Test differences $(\alpha=0.05)$.

was established in 1994, with Feteasca regala variety, clone $21 \mathrm{Bl}$, grafted on Kober $5 \mathrm{BB}$ rootstock, spaced by $2.2 \mathrm{~m}$ (inter-row) and $1.2 \mathrm{~m}$ (intra-row), with a density of 3787 plant $\cdot \mathrm{ha}^{-1}$. The vines are trained as bilateral cordon with a spur pruning system and loading of $10 \mathrm{buds} / \mathrm{m}^{2}$.

The plantation is located on a plane surface with reddish preluvosol soil and rows direction $\mathrm{N}-\mathrm{S}$. The total titratable acidity ( $\mathrm{g} / \mathrm{l}$ tartaric acid), Brix $(\% \mathrm{~m} / \mathrm{m})$, yield ( $\mathrm{kg} / \mathrm{vine})$, average weight of a berry $(\mathrm{g})$, were determined every year on $10^{\text {th }}$ of September during the past 21 years.

\section{Results and discussions}

Trends of climate variables in Bucharest. In the context of current increased interest in the global warming research, the climate trend for the past 51 years has been analysed for Bucharest area too. Table 1 presents the main climatic variables and bioclimatic indices for the experimental period compared to the reference period.

A significant increase in the average maximum temperature of warmest month $\left(+1.99{ }^{\circ} \mathrm{C}\right)$ and for the entire summer period $\left(+1.89^{\circ} \mathrm{C}\right)$ is observed. Moreover, the minimum temperature of the growing season increased too, but with a lower magnitude $\left(+0.41^{\circ} \mathrm{C}\right)$, while the average of absolute minimum temperature, ${ }^{\circ} \mathrm{C}$ significantly decreased by $2.89^{\circ} \mathrm{C}$.

On the other hand, regarding the absolute minimum temperature of the reference and current period, a decrease by $-2.0{ }^{\circ} \mathrm{C}$ is observed. There is also an insignificant increase in annual precipitations and a small statistically insignificant decrease of rainfall during the summer months. With regard to bioclimatic indices, there is a clear increase in Huglin index and Winkler index, while in the Cool night index there is no statistical significant difference.

A restrictive factor for vine cultivation (in viticulture) is the frequency of minimal cold temperatures (harmful for the vine) during the winter. In the conditions of the temperate continental climate in southern Romania, characterized by cold winters (frosty winters), it is very important that the minimal temperatures harmful for the vine, $-20^{\circ} \mathrm{C}$ for table varieties and $-22^{\circ} \mathrm{C}$ for wine [20], are not attained or exceeded. From Table 2 it can be observed the frequency of minimal harmful temperatures for the vine recorded in the last decades compared to the reference period (1961-1997).

During the reference period during 1961 to 1997 the minimum temperatures below $-20^{\circ} \mathrm{C}$ happened in 7 out 
Table 2. Minimum temperatures below $-20^{\circ} \mathrm{C}$ recorded in Bucharest-Baneasa during 1998-2018 compared to the reference period 1961-1997.

\begin{tabular}{cl}
\hline $\mathbf{1 9 6 1 - 1 9 9 7}$ & $\mathbf{1 9 9 8}-\mathbf{2 0 1 8}$ \\
\hline 1963: $-23.7^{\circ} \mathrm{C}(18.01 .1963)$ & $1998:-20.3^{\circ} \mathrm{C}(25.12 .1998)$ \\
1969: $-21.7^{\circ} \mathrm{C}(05.02 .1969)$ & $2002:-25.7^{\circ} \mathrm{C}(26.12 .2002)$ \\
1980: $-21.5^{\circ} \mathrm{C}(15.01 .1980)$ & $2003:-20.0^{\circ} \mathrm{C}(14.02 .2003)$ \\
1985: $-22.6^{\circ} \mathrm{C}(14.02 .1985)$ & $2004:-20.8^{\circ} \mathrm{C}(13.02 .2004)$ \\
$1987:-21.7^{\circ} \mathrm{C}(31.01 .1987)$ & $2005:-23.7^{\circ} \mathrm{C}(08.02 .2005)$ \\
$1990:-20.4^{\circ} \mathrm{C}(22.01 .1990)$ & $2010:-24.6^{\circ} \mathrm{C}(26.01 .2010)$ \\
$1997:-20.0^{\circ} \mathrm{C}(18.12 .1997)$ & $2012:-24.3^{\circ} \mathrm{C}(29.01 .2012)$ \\
- & $2015:-20.8^{\circ} \mathrm{C}(08.01 .2015)$ \\
- & $2016:-22.0^{\circ} \mathrm{C}(20.01 .2016)$ \\
- & $2017:-20.2^{\circ} \mathrm{C}(24.01 .2017)$ \\
\hline
\end{tabular}

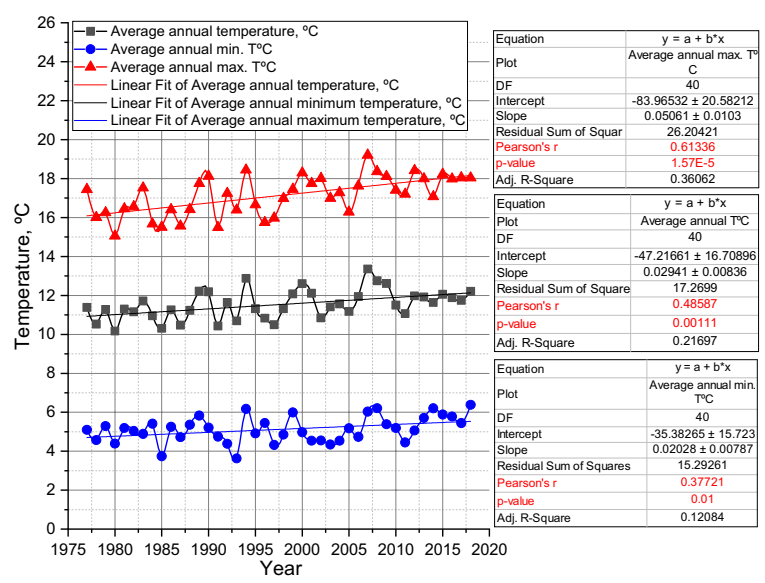

Figure 1. Average annual temperatures average annual maximum and average annual minimum temperatures in Bucharest, from 1977-2018.

of 36 years, while during 1998 to 2018 the minimum temperatures below $-20^{\circ} \mathrm{C}$ appeared more frequent, in 10 out of 21 years (Table 2).

In Fig. 1 we can observe the evolution of the average temperature, minimum and maximum averages between 1977 and 2018.

There is strong evidence in Fig. 1, that supports an increase in average annual temperature explained by a moderate positive Pearson correlation $r(40)=0.486$, $(p<0.005)$, while the linear regression equation explain only $21.7 \%$ of the variance, which means that we cannot accurately predict the future expected changes, but is relevant enough to support this trend. Similar results can be observed in the Fig. 1 for the minimum and maximum temperature. The most important increase is observed on the average annual maximum temperature, being explained by a very strong significant and strong positive Pearson correlation $r(40)=0.613,(p<0.001)$, this trend being better predicted by linear regression equation, which can explain $36.1 \%$ of the variance.

In Fig. 2 we can observe the evolution of the average annual temperature over the entire period. The calculated difference between the average of the present period (1998-2018) and the average of the reference period (1961-1997) seems to suggest that over time there was only a small increase, by only $+0.74{ }^{\circ} \mathrm{C}$. However, when taking into account the evolution of the average annual temperature during the entire period (1961-2018) included in Fig. 2, there is a very strong evidence of a constant

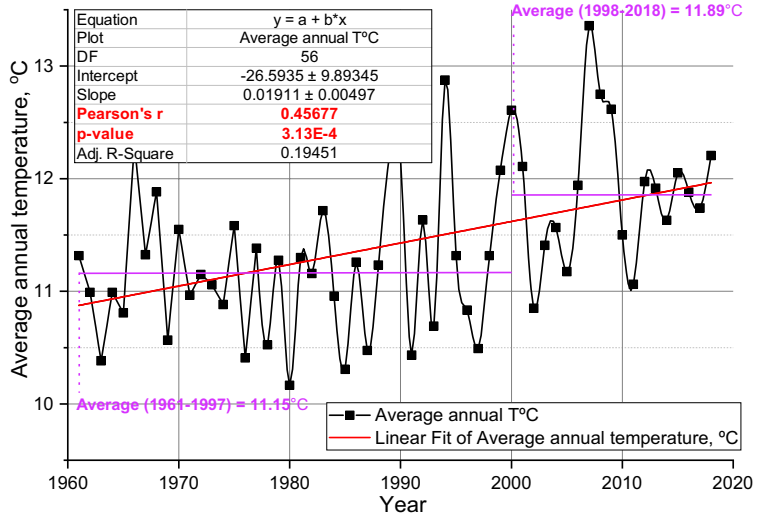

Figure 2. Evolution of the average annual temperatures in Bucharest during the period of 1961-2018.

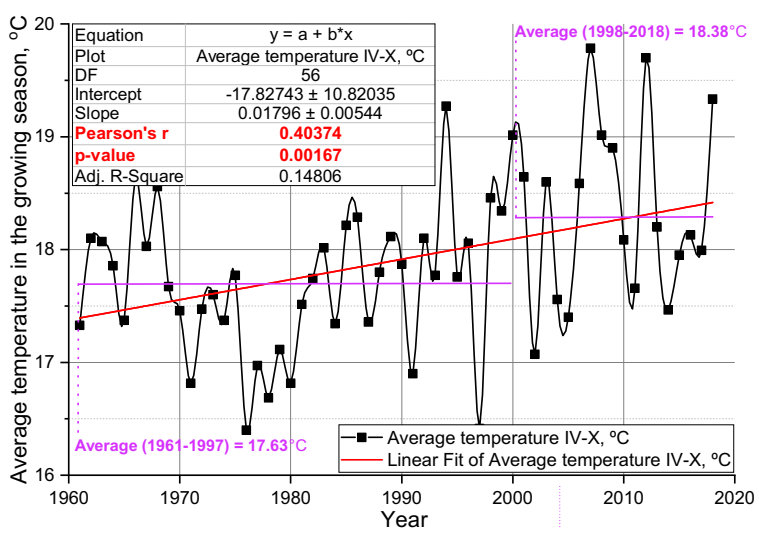

Figure 3. Evolution of the average temperatures in the growing season (months IV-X) in Bucharest (1961-2018).

tendency for increase in temperature, as also observed in the past 20 years and included in Fig. 1.

The Pearson correlation $r(56)=0.457,(p<0.001)$, supports the observation that temperature is consistently increasing in time even if the linear regression equation explains only $19.5 \%$ of the variance, meaning that the phenomenon is not really linear, but has many fluctuations. The slope of the linear equation is lower for the entire period (0.019) as compared to that of the present time period (0.029), which could be interpreted as an indication that the increase in average annual temperature accelerates.

The average temperatures in the growing season (Fig. 3) are important for viticulture and also other crops, and these showed an increase of $+0.75^{\circ} \mathrm{C}$ in the studied period (1998-2018) as compared to the reference period (1961-1997).

The evolution of the average temperature in the growing season (Fig. 3) suggests a clear increase, in a similar way as described for the rest of the temperatures presented in Figs. 1 and 2. The Pearson correlation supports this evidence, $r(56)=0.404,(p<0.05)$, while the linear regression equation explains only $14.8 \%$ of the variance for this particular case because of the very large variations in average temperature in the growing season for the years studied (1961-2018).

The most significant changes important for viticulture happen during summer (months VI-VIII), which show a difference of $+1.21^{\circ} \mathrm{C}$ between the average temperature in the summer of the studied period (1998-2018) 


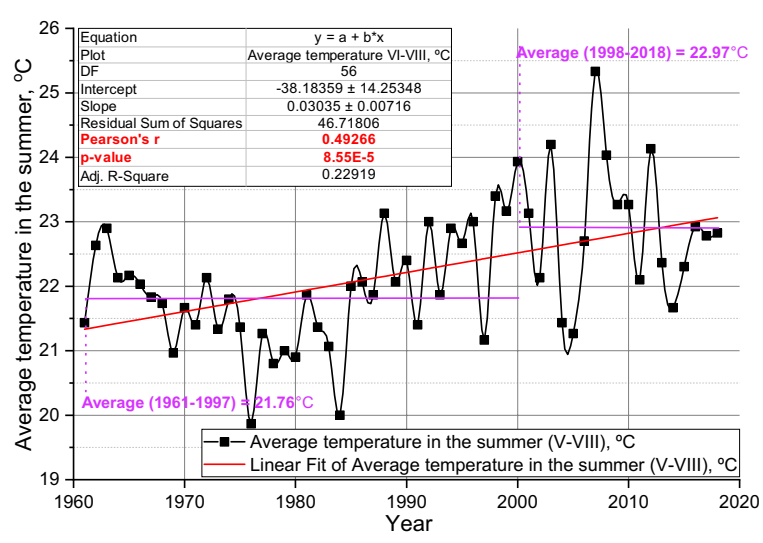

Figure 4. Evolution of the average temperatures in the summer (months VI-VIII) in Bucharest (1961-2018).

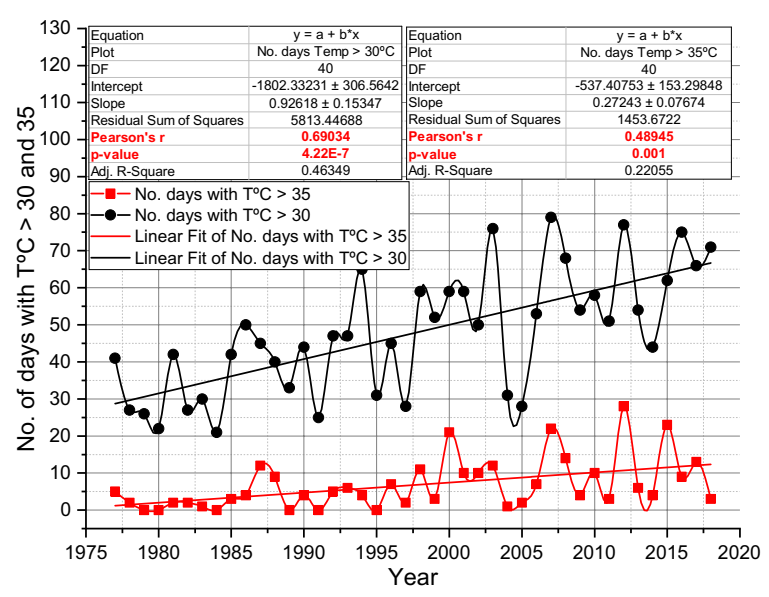

Figure 5. Number of the days with temperatures above $30^{\circ} \mathrm{C}$ and above $35^{\circ} \mathrm{C}$ in Bucharest (1977-2018).

and the reference period (1961-1997). These increased temperatures bring important changes in the maturation processes of grapes. There is a better evidence in Fig. 4 (moderate positive Pearson correlation $r(56)=$ 0.493, $p<0.001$ ), data supporting the claim that average temperature in the summer increased systematically over the years. The linear regression equation explains $22.9 \%$ of the variance, again showing that the trend is not linear and fluctuations from one year to another are important as well.

Most importantly, in recent decades there has been a significant increase in the number of hot days $\left(T>30^{\circ} \mathrm{C}\right)$ and very hot days $\left(T>35^{\circ} \mathrm{C}\right)$ (Fig. 5). The results showed a clear increase of the number of hot days $\left(T>30^{\circ} \mathrm{C}\right)$ during 1977 to 2018, proved by a strong positive Pearson correlation $r(40)=0.690,(p<0.001)$. Also, the linear regression of the data explain $46.3 \%$ of the variance which suggests it could be used for the prediction of future similar changes. The very hot days $\left(T>35^{\circ} \mathrm{C}\right)$, over the same period of 1977 to 2018 , showed a similar trend, but to a lower magnitude.

Following the evolution of the Huglin index between 1977 and 2018 (Fig. 6), there was very strong significant increase in its values, exceeding the limit in the last decade from the warm temperate (IH +1 class) to the warm climate (IH +2 class). The increase of Huglin index is proven by a moderate positive Pearson correlation $r(40)=$ 0.592, $(p<0.001)$. The linear fitting of the data explains

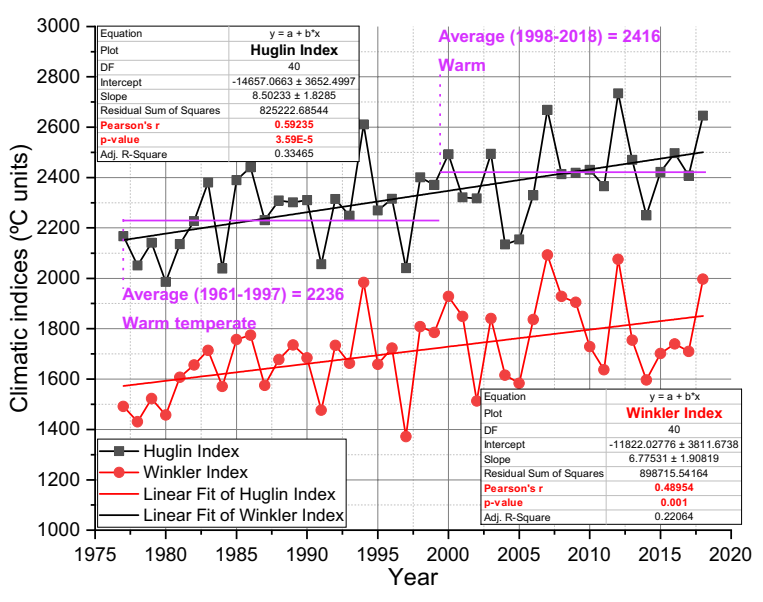

Figure 6. Climatic indices evolution in Bucharest (1977-2018).

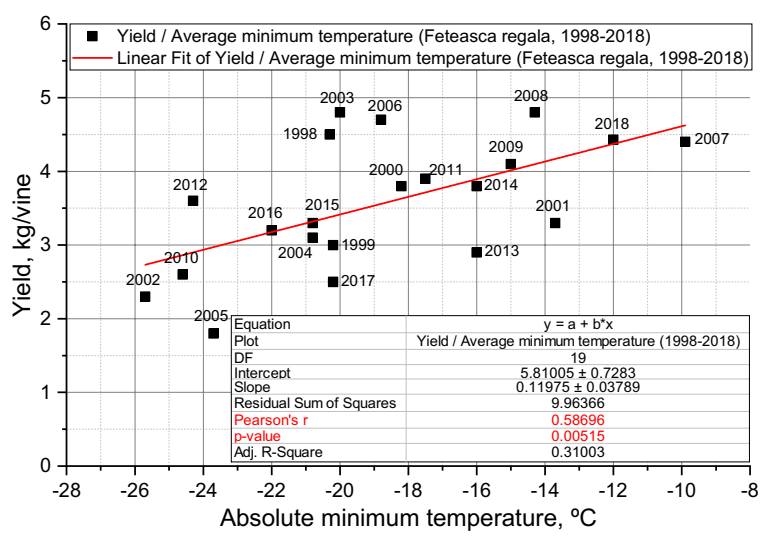

Figure 7. The negative effect of winter temperatures on grape yield (Fetească regală, Bucharest 1998-2018).

$33.5 \%$ of the variance. However, a strong significant moderate increasing trend is also observed on Winkler index (Pearson correlation $r(40)=0.490, p<0.001$ ), but in this case, the fitted line explains only $22.1 \%$ of variance.

\section{Behaviour of Fetească regală variety in the studied period (1998-2018)}

The grape yield, expressed in $\mathrm{kg} / \mathrm{vine}$, recorded large variations from one year to other (Fig. 7), from the minimum of 1.8 to a maximum 4.8 , mainly due to the frequency of minimum harmful temperatures for vines in winter, specific for the conditions of Romanian Plain. Unsurprisingly, the lower the temperature in the winter, the lower the yield (Pearson correlation $r(19)=0.587$, $p<0.01)$.

Compared to the yield obtained in normal winter conditions (with minimum temperatures down to -10 ... $-12{ }^{\circ} \mathrm{C}$ ), the drop in the minimum temperature to $-20 \ldots$ $-22{ }^{\circ} \mathrm{C}$ leads to yield losses of $30-35 \%$ or greater. The yield recorded under such conditions is still good, due to the fact that Fetească regală variety is characterized by a better fertility of the secondary shoots.

The observations regarding the effect of precipitations during the summer season showed an increase in average weight of a berry and an increase in total titratable acidity (Fig. 8).

The increase in total titratable acidity is correlated to the increase in precipitations (Pearson correlation 
Table 3. Multiple regression parameters and statistics intended for prediction of sugar accumulation (Brix) and total titratable acidity.

\begin{tabular}{lcccc}
\hline $\begin{array}{l}\text { Multiple regression } \\
\text { parameters }\end{array}$ & \multicolumn{2}{c}{$\begin{array}{c}\text { Brix, \% }(\mathbf{Y}) \\
\text { Adj. } \mathbf{R}^{\mathbf{2}}=\mathbf{0 . 5 6}\end{array}$} & \multicolumn{2}{c}{$\begin{array}{c}\text { TTA, } \mathbf{g} / \mathbf{l}(\mathbf{Y}) \\
\text { Adj. } \mathbf{R}^{\mathbf{2}}=\mathbf{0 . 7 4}\end{array}$} \\
\cline { 2 - 5 } & \multicolumn{2}{c}{$\boldsymbol{( \boldsymbol { p } \text { -value } = \mathbf { 0 . 0 0 5 1 2 } )}$} & \multicolumn{2}{c}{$\boldsymbol{p}$-value $=\mathbf{1 . 6 5 1 7 7 E}-\mathbf{4})$} \\
\cline { 2 - 5 } & Value & $\mathbf{S E}$ & Value & $\mathbf{S E}$ \\
\hline Intercept & 18.7266 & 10.0287 & 6.4278 & 5.5530 \\
Precipitations $\left(\mathrm{X}_{1}\right)$ & 0.0015 & 0.0018 & 1.4984 & 0.3273 \\
Med. $T^{\circ} \mathrm{C} \mathrm{WM}{ }^{*}\left(\mathrm{X}_{2}\right)$ & -2.2712 & 0.5912 & $8.14 \mathrm{E}-4$ & $9.72 \mathrm{E}-4$ \\
Max. $T^{\circ} \mathrm{C} \mathrm{WM}^{*}\left(\mathrm{X}_{3}\right)$ & 1.2230 & 0.5195 & -1.0984 & 0.28767 \\
Days $T>30^{\circ} \mathrm{C}\left(\mathrm{X}_{4}\right)$ & 0.0025 & 0.0453 & -0.0280 & 0.0251 \\
Days $T>35^{\circ} \mathrm{C}\left(\mathrm{X}_{5}\right)$ & 0.0658 & 0.0484 & -0.0537 & 0.0268 \\
Huglin Index $\left(\mathrm{X}_{6}\right)$ & 0.0069 & 0.0037 & $-7.23 \mathrm{E}-5$ & 0.0021 \\
\hline
\end{tabular}

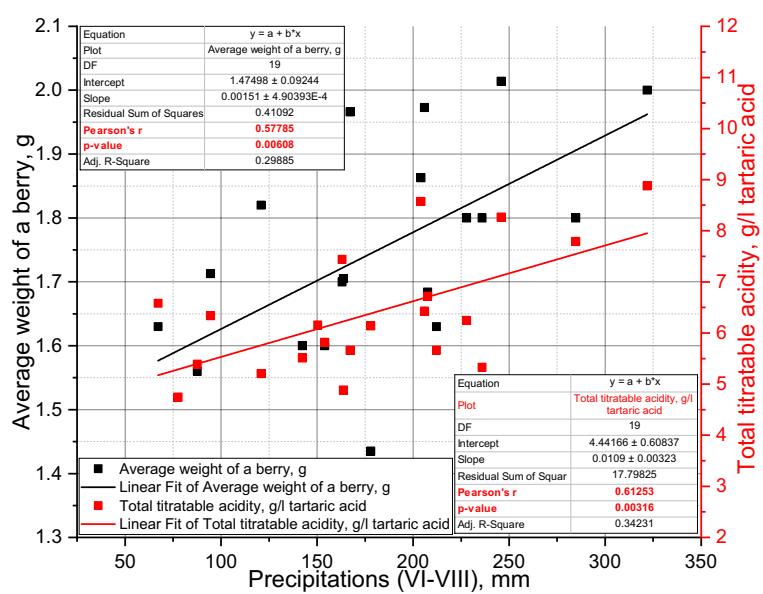

Figure 8. The effect of the precipitations in the summer season on the average weight of a berry and titratable acidity (Fetească regală, Bucharest, 1998-2018).

$r(19)=0.613, p<0.005$ and $R^{2}=0.34$ in case of linear regression). The variations regarding total titratable acidity in grape must were large enough to cause significant sensory impact in final wine, with a minimum $4.74 \mathrm{~g} / \mathrm{l}$ tartaric acid and a maximum of $8.88 \mathrm{~g} / \mathrm{l}$ tartaric acid. Fetească regală variety is known by oenologists for its good acidity and does not require corrections in most of the wine regions. The average weight of a berry is increased too with the precipitations during summer (Pearson correlation $r(19)=0.578, p<0.01, \mathrm{R}^{2}=0.29$ for the linear regression). The variations of the average weight of a berry ranged from 1.40 to 2.02 grams.

The greatest influence on the grape quality parameters was found to be described by Huglin index (Fig. 9). The effect of Huglin index on sugar accumulation (Brix) is also well demonstrated (Pearson correlation $r(19)=0.557$, $p<0.01, \mathrm{R}^{2}=0.27$ for linear regression). A negative correlation is observed for Huglin index and acidity (the total titratable acidity decreased with the increased values of Huglin index, Pearson correlation $r(19)=-0.624, p<$ $0.005, \mathrm{R}^{2}=0.36$ for linear regression).

When the Huglin index is less than 2400 units (warm temperate climate), the total titratable acidity is generally higher than $5.5 \mathrm{~g} / 1$ and often over $6.0 \mathrm{~g} / 1$ tartaric acid while Brix is generally lower than $22 \%$, which lead to harmonious light-bodied wines, with less than $13 \%$ vol. alcohol, typical for Fetească regală variety. On the other hand, Huglin index values above 2400 units lead to more

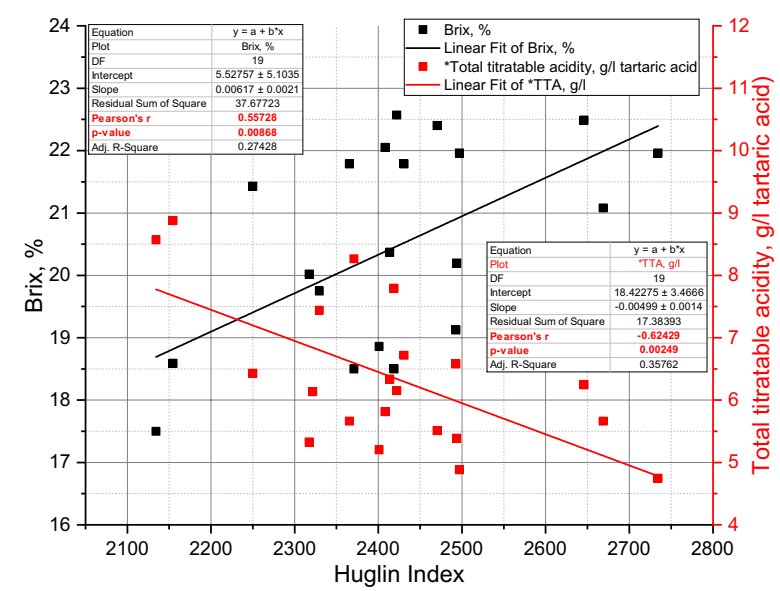

Figure 9. The effect of Huglin Index on sugar accumulation (Brix, \%) and total titratable acidity (Fetească regală, Bucharest, 1998-2018).

unbalanced wines with higher concentration in alcohol sometimes above $13.5 \%$ vol. alcohol and the mandatory need of the acidity corrections.

In order to find out which climate parameters have the most effect on grape quality a correlation was established between 6 parameters and sugar accumulation or titratable acidity, respectively, by using general multiple linear regression model. The equation used for the prediction is as follows:

$$
\begin{aligned}
Y= & b_{0}+\mathrm{b}_{1} \cdot X_{1}+\mathrm{b}_{2} \cdot X_{2}+\mathrm{b}_{3} \cdot X_{3} \\
& +\mathrm{b}_{4} \cdot X_{4}+\mathrm{b}_{5} \cdot X_{5}+\mathrm{b}_{6} \cdot \mathrm{X}_{6}
\end{aligned}
$$

Where:

Y - dependent variables: sugar accumulation (Brix, \%) or total titratable acidity (TTA, mg/l tartaric acid), $b_{0}$ - intercept; $b_{1}-b_{6}-$ slope coefficients for each of the independent variables $\mathrm{X}_{1}-\mathrm{X}_{6} ; \mathrm{X}_{1}$ - precipitations $(\mathrm{mm}) ; \mathrm{X}_{2}-$ Average temperature in the warmest month $\left({ }^{\circ} \mathrm{C}\right) ; \mathrm{X}_{3}-$ Maximum temperature in the warmest month $\left({ }^{\circ} \mathrm{C}\right) ; \mathrm{X}_{4}-$ Number of days with $T>30{ }^{\circ} \mathrm{C} ; \mathrm{X}_{5}-$ Number of days with $T>35^{\circ} \mathrm{C} ; \mathrm{X}_{6}-$ Huglin Index.

The correlation matrix along with multiple linear regression parameters are included in Table 3. As it can be seen, the multiple regression allows us to explain $56 \%$ of the variance for the sugar accumulation (Brix) and $74 \%$ of the variance for the total titratable acidity, using only six climate parameters collected during a growing season. 
The fitting function for Brix is moderately significant $(p<0.01)$, while for total titratable acidity it is strongly significant $(p<0.001)$, both correlations being better than the null hypothesis that the Brix or titratable acidity are not affected by these climatic parameters ( $\mathrm{Y}=$ constant).

\section{Conclusions}

As already proven by some other authors, the climate change is undeniable and its influences on the grape quality parameters and implicitly on the physico-chemical characteristics of wines are clearly manifested. In Bucharest too, our study proved that the climate is changing from the warm temperate (IH +1 class) to the warm climate ( $\mathrm{IH}+2$ class). As already observed, we are expecting faster grape maturation, thus the recommended harvest date, based on sugar and total titratable acidity, comes several days earlier.

Moreover, global warming brings along other climatic extremes which affect the grapevine yield and physiology and consequently wine quality. There is a tendency toward reduced precipitations during the summer, excessive number of days with temperatures over 30 and $35^{\circ} \mathrm{C}$, a lower absolute minimum temperature and more frequent winter days with temperatures below $-20^{\circ} \mathrm{C}$.

In order to produce balanced wines, the oenologists are forced to compensate for these climate changes through early harvesting, adapted canopy management for excessive temperatures and shorter exposure of vines towards light, as well as through acidity corrections in most of the years.

While the simple early harvesting is a temporary solution, this is not viable for the longer term. The maturation of other chemical constituents important for wine quality, such as aroma components and polyphenols, is also affected, depending on the period of photosynthesis, its intensity and light exposure of grapes rather than temperature and precipitations. These parameters will be followed in the next studies to obtain a better image of the impact of the observed ongoing climate changes. Other solutions, suggested by some authors too [21] would be replacement of early varieties with late ripening ones or relocation to higher elevation regions.

\section{References}

[1] L. Dejeu, M. Patic, D. Mereanu, G.M. Savu (Bucur), C. Gutue, $31^{\text {st }}$ World Congress of Vine and Wine (Italia, Verona, 2008)

[2] V.V. Cotea, L. Rotaru, L.M. Irimia, L.C. Colibaba, S. Tudose Sandu-Ville. $31^{\text {st }}$ World Congress of Vine and Wine (Italia, Verona, 2008)
[3] G.M. Bucur, L. Dejeu, G. Cazan, A. Tănase, Scientifical Papers U.S.A.M.V. Bucharest, seria B, LVI, 43 (2012)

[4] L. Rotaru, L.C. Colibaba, A.I. Prisăcaru, Lucrări ştiinţifice USAMV Iaşi, Seria Horticultură, 56, 303 (2013)

[5] G.M. Bucur, L. Dejeu, Int. Conf. "Agriculture for Life, Life for Agriculture", Horticulture, Bucharest, LVIII, 133 (2014)

[6] G.M. Bucur, L. Dejeu, AgroLife Sci. J. 5, 24 (2016)

[7] G.M. Bucur, A.C. Babeş, Bulletin UASVM Horticulture 73, 126 (2016)

[8] G.M. Bucur, L. Dejeu, Sciendo 1, 268 (2018)

[9] A. Şerdinescu, L. Pîrcălabu, V. Enache, A. Ranca, M. Bosoi, E. Dumitru, I. Rătoi, $36^{s t}$ World Congress of Vine and Wine, 2-7 June (Bucharest, 2013)

[10] L.M. Irimia, C.V. Patriche, B. Roşca, Appl. Ecol. Environ. Res. 15, 755 (2017)

[11] L.M. Irimia, C.V. Patriche, O.C. Murariu, Appl. Ecol. Environ. Res. 16, 2663 (2018)

[12] A.C. Malheiro, J.A. Santos, H. Fraga, J.G. Pinto, Clim. Res. 43, 163 (2010)

[13] C. van Leeuwen, Ph. Darriet, J. Wine Econ. 11, 150 (2017)

[14] E.M. Wolkovich, I. Garcìa de Cortàzar-Atauri, I. Morales-Castilla, K.A. Nicholas, T. Lacombe, Nat. Clim. Change 8, 29 (2018)

[15] D. Blanco-Ward, A. Ribeiro, D. Barreales, J. Castro, J. Verdial, M. Feliciano, C. Viceto, A. Rocha, C. Carlos, C. Silveira, A. Miranda, BIO Web of Conferences 12, 41 $1^{\text {st }}$ World Congress of Vine and Wine (Uruguay, Punta del Este, 2018)

[16] B. Koch, F. Oehl, Agric. Sci. 9, 247 (2018)

[17] A.J. Winkler, J.A. Cook, W.M. Kliewer, I.A. Lider, (Berkeley, General Viticulture University of California Press, 1974), p. 740

[18] P. Huglin, In Symposium International sur l'Écologie de la Vigne, l'Constanta, Roumanie (Alimentaire, Ministère de l'Agriculture et de l'Industrie 1978), p. 89

[19] J. Tonietto, A. Carbonneau, Agric. Forest Meteorol. 124, 81 (2004)

[20] M. Oşlobeanu, M. Macici, M. Georgescu, V. Stoian, Zonarea soiurilor de viţă-de-vie în România (Editura Ceres, Bucureşti, 1991)

[21] G.C. Koufos, Th. Mavrommatis, S. Koundouras, G. Jones, Temperatura - Viticultura relationships in Greece, 8th Symposium of the OENOVITI International Network (Athens, 2019), 6-9, May 13 